\title{
Jak se projevuje úroveň zákonných a technických předpisů na aplikaci modrozelené infrastruktury
}

\section{JIŘí VÍTEK}

Klíčová slova: hospodaření s deštovou vodou - modrozelená infrastruktura - městské odvodnění - Operační program Životní prostředí

\section{SOUHRN}

Česká republika v dostatečné míre nevytváří předpoklady pro koncepční prístup k odvodňování měst a obcí podle principů udržitelného rozvoje. Ministerstvo zemědělství ČR, které má v gesci vodu, zcela ignoruje skutečnost, že adaptace urbanizovaných území na změnu klimatu mimo jiné stojí na důsledné aplikaci principů hospodaření s deštovou vodou, a to nejlépe prostřednictvím modrozelené infrastruktury. Právní a technické předpisy českého stavebnictví jsou ve vztahu k vodnímu režimu urbanizovaných území nekoncepční, nesystémové a nekoordinované. Veškerá odpovědnost tak v tomto ohledu leží na městech, které si mohou pomoci vytvořením vlastních koncepčních dokumentů s pravidly pro aplikace modrozelené infrastruktury. Jsou metody, kterými toho Ize na úrovni měst a obcí dosáhnout, účinné, a jsou využívány? Jak obce a města využívají finančních pobídek od SFŽP? Dá se lokálními postupy, dokumenty a pravidly nahradit role státu?

\section{ÚVOD}

Naše projektová kancelář se za posledních 12 let spolupodílela na vzniku několika dokumentací, které hospodaření s deštovou vodou (HDV), tento nový systém odvodňování urbanizovaných území, zaváděly do koncepcí odvodnění, do generelů odvodnění měst a do metodických príruček na úrovni systémového opatření. Pro statutární město Karviná jsme v rámci mezinárodního projektu RainDROP [1] vytvářeli metodiku, jak principy HDV začlenit do územního plánu města. Pro Hranice na Moravě jsme spoluvytvářeli zásady pro matematický model kanalizačního generelu města, kde byla rozvojová území odvodněna již podle pravidel HDV. Pro statutární město Hradec Králové jsme se podíleli na vytvoření Studie odtokových poměrů (SOP) [2], přenesení jejich principů do matematického modelu kanalizačního generelu a na Metodické příručce pro aplikaci principů HDV do praxe. Zkušenosti z Hradce Králové jsme uplatnili ve statutárním městě Olomouc, kde jsme také vytvořili SOP [3] a Metodickou příručku HDV. Oběma městům jsme doporučili vypracování Městských stavebních standardů a $v$ současnosti je pro město Olomouc zpracováváme. Výčet dokumentací, na kterých vznikaly naše zkušenosti s tvorbou a projednáváním pravidel pro zavádění HDV, je tu uveden ze stejného důvodu, jako se ve výzkumu nějakých vzorků, nebo ve vyhodnocování reakcí zkoumaných respondentů, uvádí jejich počet, aby se tím stanovila míra pravděpodobnosti, že se tento jev nebo chování lidí bude opakovat, než se tato zkušenost zobecní.
Na rozdíl od většiny článků v tomto časopise, který je zaměřený na výzkum, budou v tomto článku popsané poznatky často subjektivní, prakticky nezměřitelné a číselně nevyhodnotitelné. Často se bude jednat o chování lidí, které se ve všech projektech opakovalo, ale protože předmětem našeho zadání nebylo vyhodnocování chování zúčastněných, nezaznamenávali jsme je a nevyhodnocovali je. Časem jsme ale pochopili, že se jedná o jistý vzorec chování, který vážně mění výsledek naší práce. Bylo nutné ho vyhodnotit a třeba změnit obsah dokumentace, nebo metodické postupy v príručce, či způsob vyhodnocování výsledků matematického modelu se srážkoodtokovým dějem podle principů HDV. Práce na výše uvedených dokumentacích vyžadovala zcela nový přístup, protože jsme tvořili zcela novou dokumentaci, pro zcela nové řešení odvodnění. A toto řešení bude vyžadovat pochopení nové role vody ve městě a zásadně jiného prístupu k ní.

Když jsme vyhodnotili základní atributy současné situace ve vodním hospodářství měst z pohledu role státu a když jsme získali zkušenost se zaváděním principů udržitelného rozvoje do života měst, uvědomili si, že je potřeba tyto zkušenosti zveřejnit, i když se nejedná o žádné vědecko-výzkumné poznání.

Původnost našeho sdělení snad nelze zpochybnit, jelikož se domnívám, že naše poznatky a zkušenosti jsou unikátní.

\section{SOUČASNÁ SITUACE V APLIKACI MODROZELENÉ INFRASTRUKTURY NA ÚROVNI STÁTU}

Stavební a vodní zákon předepisují dodržování principů hospodaření s deštovou vodou nekoordinovaně, což v našich městech a obcích aplikaci modrozelené infrastruktury velmi ztěžuje. Modrozelená infrastruktura jsou prírodě blízká opatření, která vrací vodnímu režimu jeho původní podobu. Našim úkolem je srážkovou vodu bezpečně vsakovat do podzemí, zvyšovat prostřednictvím zeleně její evapotranspiraci a smysluplně ji využívat k provozu nemovitostí. Zeleň poté města a její obyvatele daleko lépe chrání před účinky dlouhotrvajícího horkého počasí. Modrozelená infrastruktura je zcela zásadním opatřením adaptace na změnu klimatu urbanizovaných území a základním nástrojem prevence proti záplavám a proti suchu.

Problém je $v$ tom, že podmínky pro aplikaci těchto opatření nejsou $v$ ČR doposud dostatečně institucionalizovány. Výklad právních predpisů týkajících se odvodňování měst je vágní a nejednoznačný. Není jasné, co má projektová príprava obsahovat, jaké jsou relevantní podklady, či jsou-li objekty HDV 
vodními díly. Stejně tak není u změn staveb a změn jejich užívání jasné, kam až sahá povinnost přebudovat/dobudovat u těchto stávajících staveb jejich odvodnění $[4,5]$. To vše vede $k$ velmi špatné vymahatelnosti těch mála předpisů, které se pro aplikaci HDV dají využít. Základním nedostatkem v aplikaci HDV je to, že ČR patří k těm mála státům Evropy, kde se za odvádění srážkové vody ze staveb k bydlení a z komunikací poplatky neplatí. Chybí tak finanční motivace pro majitele těchto nemovitostí.

Do technických předpisů jednotlivých oborů českého stavebnictví doposud nebyla zapracována a vzájemně zkoordinována pravidla pro novou roli vody a zeleně v našich městech a obcích. Stát se doposud nevyjádřil k tomu, v jakých všech aspektech lidské činnosti je nutné změnit náš prístup a chování tak, aby se naše společnost byla schopná připravit na nové klimatické podmínky. Technické normy pro komunikace a pozemní stavby doposud neintegrovaly požadavky, které jsou obsažené, nebo vyplývají z TNV 759011 Hospodaření se srážkovými vodami. Nejpatrnější je to u ČSN 736005 Prostorové uspořádání sítí technického vybavení. V této normě objekty decentrálního odvodnění, resp. modrozelené infrastruktury vůbec nefigurují, tzn. že v uličních profilech není definována poloha inženýrských sítí vưči MZl, jejich vzájemné situační a výškové uspořádání, nejsou stanovena ochranná pásma.

Připravit města a obce na změnu klimatu vyžaduje změnit v mnoha oborech náhled a myšlení všech, kteří nemovitosti staví, schvalují a povolují, nebo v nich bydlí. V procesu výstavby zejména staveb pro bydlení je státní správa jedinou instancí, která mưže dodržování pravidel udržitelného rozvoje zajistit. Snaha některých developerů tato pravidla obcházet, vyžaduje, aby státní správa měla k dispozici kvalitní právní a technické předpisy, kterým bude rozumět a nebude o nich pochybovat.

\section{METODY, JIMIŽ LZE MODROZELENOU INFRASTRUKTURU DO MĚST A OBCÍ INTEGROVAT}

Letitá stagnace zájmu odpovědných ministerstev vytvořit ucelené a sladěné právní a technické předpisy nás v průběhu let vedla k podpoře měst a obcí, aby si vytvárela územně plánovací dokumentace s integrovanými pravidly pro aplikaci modrozelené infrastruktury, které budou platné a závazné na katastrech, který spravují. V tomto doporučení jsme vycházeli z toho, že Ize využít těch paragrafư z platných zákonů, které se HDV zabývají a nevšímat si těch, které jsou s nimi v rozporu.

Na základě našich zkušeností, které jsme učinili zejména v Hradci Králové a Olomouci, se domníváme, že k tomu, aby si města a obce vytvořla předpoklad pro systémový prístup k decentrálnímu odvodnění a aplikaci MZI, tak si musí vytvořit tři klíčové koncepční dokumenty - Studii odtokových poměrů, Městské stavební standardy a Metodickou př́ručku pro aplikaci HDV, resp. MZI.

\section{STUDIE ODTOKOVÝCH POMĚRŮ (SOP) - KONCEPCE ODVODNĚNÍ MĚSTA}

Většina českých měst má koncepci odkanalizování a odvodnění definovanou kanalizačním generelem. Tyto generely vychází z pasportů kanalizace a prostřednictvím matematického modelu město získává informace o provozních stavech ve stokové síti podle toho, jak se bude rozvíjet. Tyto generely byly vytvořeny na konvenční odvodnění, v době, kdy se ještě principy HDV neznaly. $\checkmark$ současnosti je jen málo měst, jejichž kanalizační generely, resp. jejich matematické modely stokové sítě mají principy HDV do sebe zapracovány na úrovni systémového opatření. Srážkoodtokový děj konvenčního odvodnění, kdy voda odtéká nejkratší cestou z pozemku do kanalizace, nebo řeky, je zcela jiný, než je tomu u decentrálních systémů odvodnění, které principy HDV naplňuje. Když uvážíme, že stavební zákon vyhláškou č. 501/2006 Sb. předepisuje povinnost regulovat odtok srážkových vod ze všech nových staveb od roku 2007 a zákon o vodách č. 254/2001 Sb. tuto povinnost od 1. 8. 2010 vztahuje i na stávající zástavbu, na které provádíme změny nebo měníme jejich užívání, tak je snad nejvyšší čas generely aktualizovat.

Tomu by ale mělo předcházet vytvoření koncepce odvodnění města tzv. studie odtokových poměrů. Základní smysl a význam zároveň tohoto dokumentu je v tom, že v zemi, kde je chaos v dodržování výše uvedených právních ale i technických předpisů, získá město dokument, který mu umožní mít představu o tom, jaká opatření se na celém území města mají či mohou aplikovat. Jak vypadá povinnost ctít principy HDV tam, kde jejich aplikace jednoduchá, jak tam, kde je komplikovaná a tam, kde aplikace principů HDV je velmi omezená.

Koncepce odvodnění ze zásad HDV vytvoři systémová pravidla a opatření, podle kterých se ve městě začne stavět a přestavovat veškerá zástavba při dodržení principů udržitelného rozvoje. Smyslem HDV je prevence proti záplavám a tím se stává nedílnou součástí adaptace na změnu klimatu. Je nanejvýš vhodné, aby si města spolu s koncepcí odvodnění tvořila koncepci prevence proti suchu a celé se to spojilo do jednoho dokumentu, který bude součástí celkové adaptace města na změnu klimatu.

SOP - koncepce odvodnění města podle principů HDV přináší:

- snížení dopadů lokálních záplav, kdy na relativně malou urbanizovanou plochu spadne obrovské množství vody (jev, který změnu klimatu charakterizuje);

- zmenšení podílu čisté srážkové vody v jednotné kanalizaci, čímž se sníži počet přepadů na odlehčovacích komorách;

- snížení podílu zředěné odpadní vody $v$ povrchových tocích - sniží se tím četnost hydraulických a látkových šoků, které řeky a potoky při prívalových srážkách dostávají;

— zvýšení dotace podzemních vod;

— zvýšení vlhkosti ovzduší v zástavbě s MZl, která město ochlazuje při dlouhých obdobích sucha, kdy roste počet tropických dnů (jev, který změnu klimatu charakterizuje).

$\checkmark$ rámci tvorby koncepce odvodnění města se dokonale zmapují možnosti aplikace HDV ve stávající zástavbě a to, jaký to bude mít vliv na kapacitu stokové sítě, čistotu povrchových toků, které jím protékají a režim podzemních vod.

Zaměření SOP odpovídá účelu, jakému má sloužit a obsahuje:

- zmapování potenciálu města či obce, ve které stávající zástavbě Ize aplikovat principy HDV a za jakých podmínek Ize stávající konvenční odvodnění přestavět na decentrální, popř. integrovat MZl;

- definování podmínek aplikace modrozelené infrastruktury pro novostavby;

- vyhodnocení území z hlediska významu místních vodních režimů, která jsou pro jakoukoli výstavbu nevhodná až nezpůsobilá;

- analýzu větších rozvojových ploch - stanovení podmínek, za jakých bude možné do nich postupně a nepravidelně vstupovat, aniž by byla ohrožena bezpečná aplikace modrozelené infrastruktury;

— zapracování principů HDV do kanalizačního generelu města.

SOP se dělí:

A. podle legislativy ČR - je nanejvýš vhodné sladit výklady právních předpisů na obou úrovních státní správy;

B. podle stupně PD - formulace závazných pravidel, která jsou specifikována pro jednotlivé typy dokumentací, stupně a fáze projektové prípravy až po predání/převzetí stavby do užívání; 
C. podle místa stavby - pro návrh a posouzení odvodnění stávající zástavby Ize využít kategorizace území a pro návrh a posouzení odvodnění novostaveb na rozvojových plochách platí pravidla a postupy předepsanév návrhu odvodnění rozvojových ploch;

D. podle principů HDV - jde o definice parametrů objektů HDV pro návrh a posouzení odvodnění všech staveb.

\section{MĚSTSKÉ STAVEBNÍ STANDARDY (MSS)}

Jak už bylo výše uvedeno, v českých technických předpisech chybí zkoordinované zásady HDV s ostatními stavebními profesemi tak, aby řešitelé a schvalovatelé projektových dokumentací věděli, jak by pozemní, dopravní a vodohospodáŕské stavby měly ve městech a obcích vypadat, aby splňovaly zásady udržitelného rozvoje. Pokud si chce město zajistit podstatně jednodušší proces schvalování, může si nechat vytvořit stavební standardy zejména pro vznik pozemních a dopravních staveb, které vytvárí náhled na podobu a funkci různých typů staveb s účastí modrozelené infrastruktury.

Městské stavební standardy je dokument, který nabízi škálu opatření, jednotlivé prvky MZl, kterými Ize dosáhnout jejich integrace do různých typů ve stávající zástavbě nebo při výstavbě novostaveb. Vznikla zkoordinovaná pravidla, konstrukční a zásady o vzájemném uspořádání jednotlivých staveb na veřejném prostranství a na soukromých pozemcích.

Smyslem městských stavebních standardů není poskládání jednotlivých funkcí podle toho, co se kam vejde. Tým řešitelů musí být složen z profesionálů $\checkmark$ jednotlivých oborech a musí k zadání přistoupit citlivě a městotvorně. Hlavní zásadou musí být, že je úkolem vytvořit zkoordinovaná pravidla a kritéria, nikoli katalog typových řešení. Tvưrčí kreativita urbanistů, architektů, dopravních inženýrů a krajinářů, kteři se pravidly budou rídit, nesmí být omezena. Aplikace modrozelené infrastruktury nesmí být na úkor ostatních profesí, ale v souladu s nimi. V současné době na takových městských standardech pro jedno město pracujeme a poznatky jsou nesmírně zajímavé. Tím, že s podobným prístupem je zatím malá zkušenost, není úkol vưbec jednoduchý. Vidíme, jak je to složitý proces, co všechno je nutné skloubit a vyladit, aby vznikly vhodné podmínky pro na oko jednoduchá a přitažlivá řešení, která vidíme v zahraničí.

Další důležitou podmínkou úspěšného použití stavebních standardů je, aby si města vytvořila procesní opatření, jimiž si města a obce zajistí na katastru svého území jejich závaznost a vymahatelnost. Způsob, jak si statut závaznosti zajistit, se nabízí schválení MSS jako součást územně analytických podkladů územního plánu, nebo vypracováním územních studií. Domníváme se, že s ohledem na malou zkušenost s kritérii pro aplikace MZI do města by bylo vhodné tato pravidla po nějakém čase seriózně vyhodnotit a zkvalitnit.

\section{METODICKÁ PŘÍRUČKA PRO APLIKACI MZI}

Na základě zkušeností s vytvářením a projednáváním dvou studií odtokových poměrů musím konstatovat, že bez metodické příručky pro aplikaci MZI se státní správa neobejde.

Metodická príručka je přehled opatření, procesních postupů a vazeb, jak s dokumenty jako jsou studie odtokových poměrů a městské stavební standardy zacházet, jakým způsobem ve městě zajistit smluvními vztahy kvalitní podmínky pro předávání a prebírání staveb MZI do užívání města, pravidla pro provoz a údržbu MZI, nebo to, aby vstupem prvního developera do území celá koncepce odvodnění nějaké větší rozvojové oblast nevzala za své. Z pohledu měst je potřeba k zavádění principů HDV mít k dispozici taková organizační opatření, která jsou převážně neinvestičního charakteru.
Státní správa je často při vymáhání dodržování předpisů o HDV, resp. MZI ve složité situaci, protože jí brání:

- efektivnější vnitřní organizace, procedurální nedostatky př̀i schvalování, povolování a kolaudování staveb;

- neurčený provozovatel městských systémů HDV a zeleně, jež je součástí MZI s jasně definovanými povinnostmi v provozní smlouvě;

- kvalitnísmlouvy mezi městy a developery o předávání a přebírání modrozelené infrastruktury do majetku města;

- podpora a ochota samosprávy investovat do výše uvedených koncepčních dokumentů.

Metodická př́ručka je cesta, jak zabránit vzniku nekvalitních, nezákonných a nebezpečných staveb.

\section{PILOTNÍ PROJEKTY - MOŽNOST FINANCOVÁNÍ Z OPERAČNIIHO PROGRAMU ŽIVOTNÍ PROSTŘEDÍ}

V současné době se Státní fond životního prostředí ČR snaží motivovat majitele nemovitostí k jinému prístupu ke srážkové vodě prostřednictvím dotací z Operačního programu Životní prostředí (OPŽP). V OPŽP se nachází řada dotačních pobídek, které mohou pomoci městům a obcím zavádět systémy HDV a srážkovou vodu využívat jako vodu užitkovou. Takto podporované projekty se mohou stát ukázkovými stavbami, které pomohou ve společnosti změnit náhled na problematiku HDV, jakožto celé adaptace na změnu klimatu.

V Prioritní ose 1 OPŽP jsou podporovány projekty na přizpůsobení se změnám klimatu. Jedná se zejména o Specifický cíl 1.3 na zajištění povodňové ochrany intravilánu a hospodaření se srážkovými vodami. Podpora v rámci tohoto specifického cíle je poskytována z prostředků Státního fondu ve výši 85 \% celkových způsobilých výdajů. Podpora se týká zejména projektů zaměřených na aplikaci hospodaření se srážkovou vodou na stávajících stavbách v intravilánu, tzn. na odpojování srážkových vod z nemovitostí od jednotné kanalizace. U výměny nepropustných zpevněných povrchů za propustné zpevněné a propustné povrchy je podpora poskytována ve výši 50 \% celkových způsobilých výdajů.

Oprávnění žadatelé a príjemci podpory jsou kraje, obce, dobrovolné svazky obcí, organizační složky státu, státní podniky, státní organizace, veřejné výzkumné instituce a výzkumné organizace, pokud jsou veřejnoprávními subjekty, městské části hl. města Prahy, příspěvkové organizace, vysoké školy a školská zařízení, nestátní neziskové organizace (obecně prospěšné společnosti, nadace, nadační fondy, ústavy, spolky).

Města a obce mohou využít dotace $k$ realizaci pilotních projektů, na kterých ukáží, jak adaptace na změnu klimatu v městském či obecním prostředí vypadá. $V$ rámci aktivity 1.3.2 OPŽP mezi podporované typy projektů patří opatření a stavby zajištujuící prevenci proti záplavám a zároveň prevenci proti suchu: - povrchová vsakovací a retenční zařízení doplněná zelení (plošný vsak, průleh, průleh s rýhou, vsakovací nádrž),

- podzemní vsakovací zařízení s retenčním prostorem vyplněným štěrkem nebo prefabrikáty

— povrchové či podzemní retenční prostory s regulací odtoku do povrchových vod nebo kanalizace (suché retenční nádrže, retenční nádrže se zásobním prostorem, podzemní retenční nádrže, umělé mokřady),

- akumulační podzemní nádrže na zachytávání srážkových vod pro jejich opětovné využití (např. na zálivku či splachování WC),

— výměna nepropustných zpevněných povrchů za propustné zpevněné a propustné povrchy se součinitelem odtoku každého z nových povrchů do 0,5 včetně, 
- přestavby konstrukcí střech s okamžitým odtokem srážkové vody (keramické, plechové atd.) na povrchy s akumulační schopností (vegetační, retenční) se součinitelem odtoku do 0,7 včetně.

Souhrn podmínek je následující:

- odpojením srážkových vod z nemovitostí od jednotné kanalizace se Ize poplatku úplně zbavit, když se vody po zadržení regulovaně odvedou do povrchového toku, nebo ho výrazně zredukovat vhodnou retencí a využíváním srážkové vody k provozu těchto nemovitostí;

— v současné době lze žádat o finanční podporu na prestavbu odvodnění, výstavbu zařizení k využivání srážkové vody na provoz nemovitosti z výše uvedené dotace OPŽP do začátku ledna př́štího roku;

- výčet uznatelných položek je dostačující (veškerá projektová príprava až po kolaudaci stavby) a pravděpodobnost získat dotaci je vzhledem k minimu žádostí značná:

- podmínkou pro podání žádosti je právoplatné územní rozhodnutí a rozpracovaná dokumentace ke stavebnímu povolení do takové podrobnosti, aby bylo možné rozpočtem stanovit investiční náklady stavby;

— žádost se podává elektronicky emailem a zaměstnanci OPŽP s vyplněním formuláre městům a obcím jsou pripraveni pomoci.

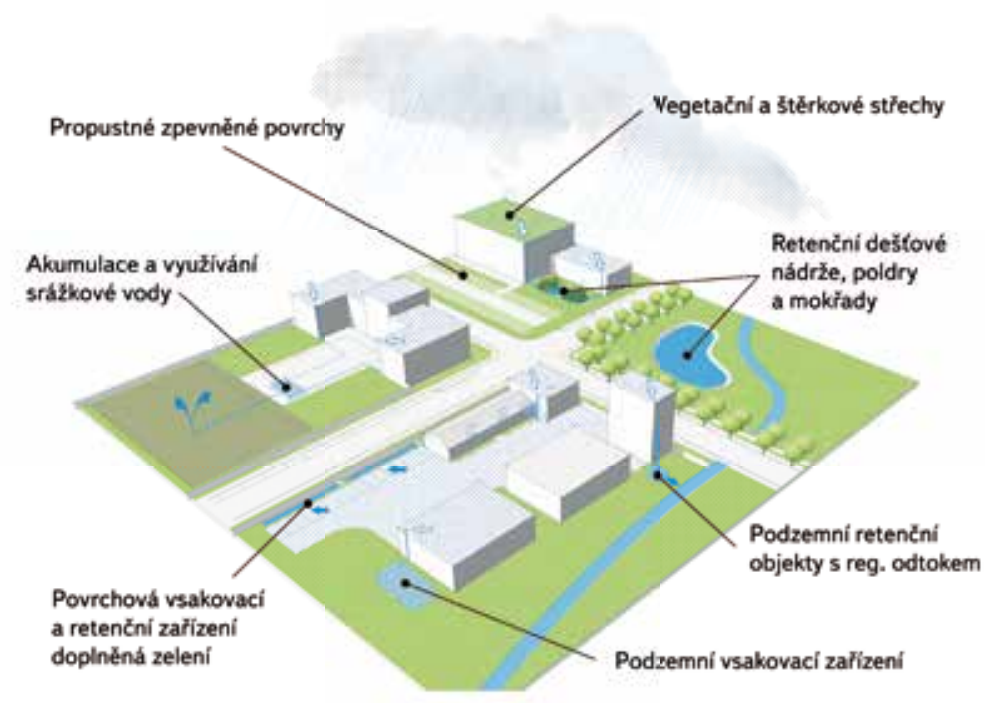

Obr. 1. Přehled základních objektů a zařizení hospodařících s deštovou vodou (zdroj: JV PROJEKT VH, s. r. o.)

Fig. 1. Overview of main SuDS measures (source: JV PROJEKT VH, s. r. o.)

\section{JSOU METODY INTEGRACE MODROZELENÉ INFRASTRUKTURY DO MĚST A OBCÍ VYUŽÍVÁNY?}

Z výše uvedeného popisu jednotlivých dokumentací by se mohlo zdát, že se jedná o celkem propracovaný návod, jak organizačně, právně, technicky i metodicky k systémové implementaci principů HDV do života měst a obcí přistoupit (obr. 1).

Přehled toho, co by města a obce vypracováním uvedených dokumentací získaly, jak by byly připraveny na budoucnost a jaké finanční prostředky by ušetřily, je uveden $v$ následujícím textu.

\section{STUDIE ODTOKOVÝCH POMĚRŮ}

Vytvořením pravidel v rámci SOP si města a obce:

- zajistí bezpečný udržitelný rozvoj, a to velmi často za finanční prostředky soukromých investorů - obytné soubory, průmyslové areály, logistické stavby atd.;

- zajistí systém právních a organizačních opatření, jimiž pohlídají, že objekty MZI které jim budou předávány, budou v potřebné kvalitě a funkčnosti;

- vytvoři pro výhledovou zástavbu koncepce odvodnění s pravidly postupného zastavování tak, aby měla vše pod kontrolou;

— $v$ předstihu vyberou budoucí provozní společnost, která bude včas dohližet a kontrolovat projektovou prípravu, realizaci a prebírání objektů MZI do uživání a připraví se tak na provozování těchto objektů.

\section{MĚSTSKÉ STAVEBNÍ STANDARDY}

Zkoordinováním stavebních profesí v rámci MSS si města a obce:

- zajistí vytvoření pravidel pro aplikaci MZI do rekonstruovaných veřejných prostor - náměstí, nábřeží, komunikací atd.;

- vytvoří různé modelové kombinace opatření a objektů MZI, kterými mohou inspirovat soukromé investory.

\section{METODIKA PRO APLIKACI MZI}

Vypracováním metodiky si města a obce:

- vybaví státní správu a dotčené orgány státní správy jednotnými pravidly a postupy tak, aby nevznikaly nekvalitní a nebezpečné stavby, jako je tomu mnohde nyní;

- mají možnost zajistit vnitřní organizaci pro schvalování, povolování a kolaudace staveb tak, aby neunikla pozornosti, nekontrolovaně nekvalitní stavba.

\section{PILOTNÍ PROJEKTY}

Přesto, že se města a obce mohou zbavit značných režijních nákladů, je jejich vztah k využití výše uvedené dotace z OPŽP velmi chladný.

$\checkmark$ rámci několika technickoekonomických analýz, které jsme pro města a obce vypracovávali v naší firmě, jsme zjistili následující:

- poplatkům za odvádění srážkové vody z nemovitostí v majetku měst či obcí nevěnuje jejich vedení často žádnou pozornost, protože o jejich výši a poměrně snadné možnosti se jich zbavit vůbec neví;

- roční poplatky, které za odvodnění nemovitostí $v$ jejich vlastnictví města a obce platí, často u jednotlivých staveb překračují statisíce korun - jedná se např. o obecní nebo městské úřady, magistráty, základní školy, mateřské školky, sociální zařízení, nemocnice, sportovní areály, plavecké stadiony, zimní stadiony, kulturní domy, muzea, knihovny, areály technických služeb;

- u univerzitních kampusů presahují roční poplatky za odvádění srážkové vody často milión korun;

- odpojením srážkových vod z těchto nemovitostí od jednotné kanalizace se Ize poplatku úplně zbavit, nebo ho vhodnou retencí a využíváním srážkové vody k provozu těchto nemovitostí výrazně zredukovat;

- v současné době Ize žádat o finanční podporu na přestavbu odvodnění, výstavbu zařizení $k$ využívání srážkové vody na provoz nemovitosti z výše uvedené dotace OPŽP do začátku ledna príistího roku;

— výčet uznatelných položek je dostačující (veškerá projektová príprava až po kolaudaci stavby) a pravděpodobnost získat dotaci je vzhledem k minimu žádostí značná; 
— podmínkou pro podání žádosti je právoplatné územní rozhodnutía rozpracovaná dokumentace ke stavebnímu povolení do takové podrobnosti, aby bylo možné rozpočtem stanovit investiční náklady stavby;

— žádost se podává elektronicky emailem a zaměstnanci OPŽP s vyplněním formuláře městům a obcím jsou připraveni pomoci.

Na několika projektech (obr. 2-4) jsme si udělali analýzu výhodnosti využití dotace při odpojování srážkových vod od kanalizace podle pravidel Aktivity 1.3.2 Hospodaření se srážkovými vodami v intravilánu. Předložené př́klady jsou aplikace HDV na konkrétních stavbách, o kterých je uvažováno, že se stanou předmětem žádosti o dotaci z OPŽP.

Investiční náklady na odpojení srážkové vody, její retenci a regulovaný odtok jsou u jednotlivých staveb odhadnuty na základě technického řešení, o němž řešitelé předpokládají, že je reálné. Jelikož se u těchto staveb zároveň uvažuje se zateplením střech, byly u nich vyčísleny i náklady na zateplení a na prestavbu střech z plechové na vegetační.

Do návratnosti investice do odpojení srážkové vody ze školy od jednotné kanalizace spolu s prestavbou střechy byla započítána jenom ta část rekonstrukce střechy, která se netýká zateplení, ale v rámci zateplení by se musela udělat.

Těžko se chápou důvody nedostatečné prozíravosti při rozhodování o pořízení koncepčních dokumentací SOP, MSS a metodiky. Ale proč města, obce, univerzity nemotivuji výsledky technickoekonomických analýz, když platí za odvádění srážkové vody do jednotné kanalizace takové výdaje, když ke zbavení se poplatků je snadná cesta a když za šest až sedm let by měly investici poplatky umořenou.

Z informací, které máme, to nevypadá, že by se vypracování výše uvedených koncepčních dokumentací v obdobné propracovanosti zabývalo více měst, než jsou ta, o kterých je ve článku zmínka. Podle zprávy ze SFŽP není o tento dotační titul zájem.

A to nás vede k otázkám... proč, proč, proč?

Je vztah obyvatel České republiky k závěrům většiny vědců, klimatologů, hydrologů, vodohospodářů natolik nedůvěřivý, že nevyvolávají dostatečný tlak na politiky, aby se situací něco dělali?

Proč v době, kdy některé země dávaly vodě statut národního zájmu, naši vrcholní politici zpochybňovali, že vưbec změna klimatu nastala?

Proč naše země ztratila čas, po který mohla usilovat o zastavení některých následků změny klimatu a zahájit systematickou př́pravu na její adaptaci zejména v oblasti vzdělávání, výzkumu, monitoringu stavu krajiny, v analýzách vlivu na stavebnictví, dopady na zdraví atd.?

\section{ZÁVĚR}

V současnosti se řada ambiciózních projektů zasítuje pojmy "smart city", "smart regiony", což v kontextu uvedených zkušeností nezní moc presvědčivě.

Důvody toho, proč se města a obce obtí̌ně chápou role garanta adaptace na změnu klimatu na svém katastru, vidíme ve třech důvodech - $v$ nezávislosti státní správy na samosprávě - v nedostatečných vědomostech v oblasti environmentálních věd - v neznalosti ekonomických souvislostí.

Státní správa se velmi často obává používat výše uvedené koncepční dokumentace k vymáhání dodržování zásad pro aplikaci HDV, i když jsou obrazem platných zákonů a jejich prováděcích předpisů a technických norem. Navíc její nejistota také pramení z toho, že funguje dvoustupňově a na krajské úrovni nemusí souhlasit s interpretací pravidel a zásad, protože si znění zákonů vysvětlují jinak.

\section{AREÁL ZÁKLADNÍ ŠKOLY - PŘÍKLAD 1}

Velikost areálu činí 1,7 ha a poplatek za odvádění srážkové vody 120216 Kč/rok.

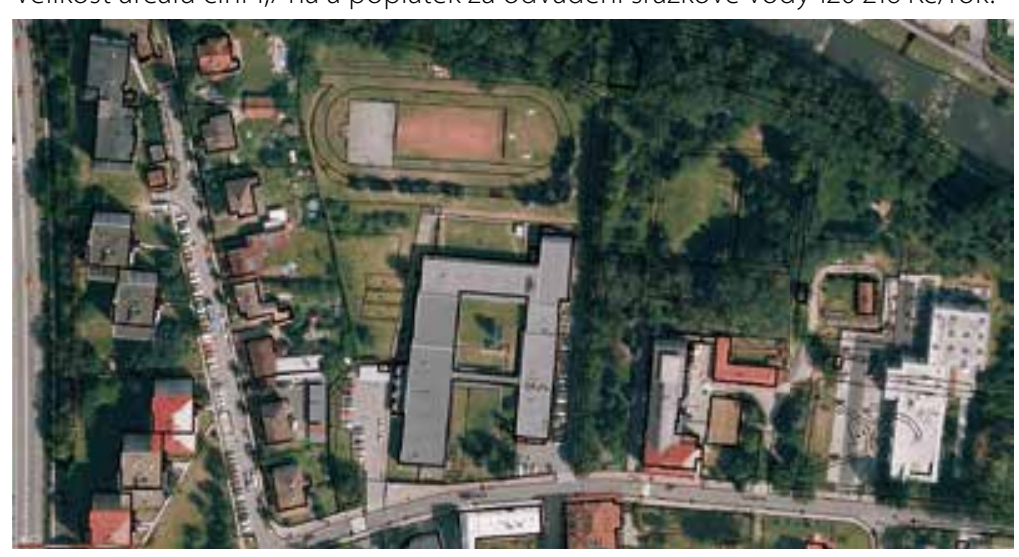

Obr. 2. Situace školního areálu (zdroj: JDTM ZK)

Fig. 2. Site layout (source: JDTM ZK)

\section{AREÁL ZÁKLADNÍ ŠKOLY - PŘíKLAD 2}

Velikost areálu činí 2,1 ha a poplatek za odvádění srážkové vody 140149 Kč/rok.

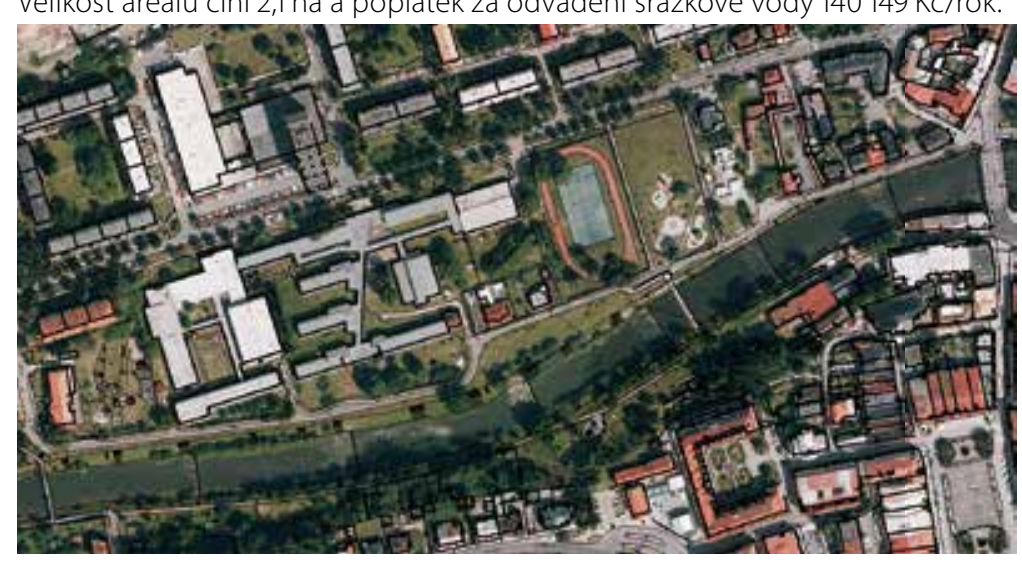

Obr. 3. Situace školního areálu (zdroj: JDTM ZK)

Fig. 3. Site layout (source: JDTM ZK)

\section{AREÁL NEMOCNICE - PŘÍKLAD 3}

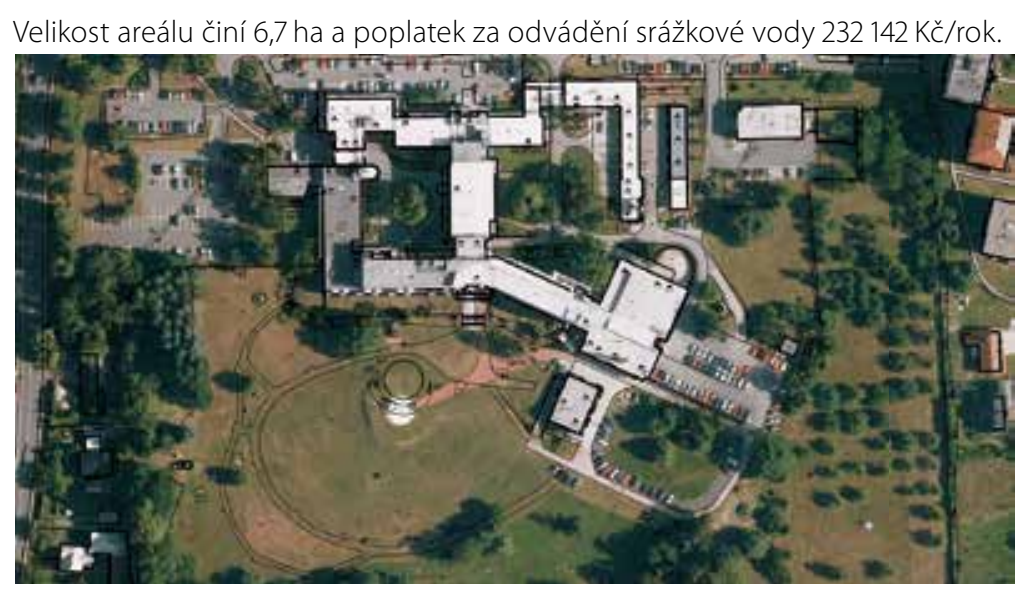

Obr. 4. Situace areálu nemocnice (zdroj: JDTM ZK)

Fig. 4. Site layout (source: JDTM ZK) 
Tabulka 1. Odhad investičnich nákladů a výpočet návratnosti (zdroj: JV PROJEKT VH, s. r. o.)

Table 1. Estimation of investment costs and payback period (source: JV PROJEKT VH, s. r. o.)

\section{ZÁKLADNÍ ŠKOLA - PŘíKLAD 1}

\begin{tabular}{|c|c|c|c|}
\hline poplatek za odvádění srážkové vody za rok 2016 & 120216 Kč & $\begin{array}{l}\text { přestavba střechy se zateplením na } \\
\text { vegetační }\end{array}$ & $\begin{array}{l}\text { rekonstrukce střechy } \\
\text { se zateplením }\end{array}$ \\
\hline velikost areálu & $17000 \mathrm{~m}^{2}$ & velikost střech & $3130 \mathrm{~m}^{2}$ \\
\hline zadání - odpojení srážkových vod od jednotné kanalizace & & \multicolumn{2}{|c|}{$\begin{array}{l}\text { zadání - porovnání nákladů na rekonstrukci střech s cenou } \\
\text { za přestavbu na střechy vegetační }\end{array}$} \\
\hline odhad investičních nákladů & 4700000 Kč & $6573000 \mathrm{Kč}$ & 3130000 Kč \\
\hline projektová příprava, žádost, výběr zhotovitele & 705000 Kč & 985950 KČ & $469500 \mathrm{Kč}$ \\
\hline celkem & 5405000 Kč & $7558950 \mathrm{Kč}$ & $3599500 \mathrm{Kč}$ \\
\hline dotace z OPŽP (85 \%) & 4594250 Kč & 6425108 Kč & \\
\hline částka z rozpočtu města (15 \%) & 810750 Kč & 1133843 Kč & \\
\hline návratnost investice & 6,7 roků & & \\
\hline částka z rozpočtu města (vč. vegetačních střech) & 1944593 Kč & & \\
\hline návratnost investice (vč. vegetačních střech) & 16,2 roků & & \\
\hline
\end{tabular}

Tabulka 2. Odhad investičních nákladů a výpočet návratnosti (zdroj: JV PROJEKT VH, s. r. o.)

Table 2. Estimation of investment costs and payback period (source: JV PROJEKT VH, s. r. o.)

\section{ZÁKLADNÍ ŠKOLA - PŘÍKLAD 2}

\begin{tabular}{|c|c|c|c|}
\hline poplatek za odvádění srážkové vody za rok 2016 & 140149 Kč & $\begin{array}{l}\text { přestavba střechy se zateplením na } \\
\text { vegetační }\end{array}$ & $\begin{array}{l}\text { rekonstrukce střechy } \\
\text { se zateplením }\end{array}$ \\
\hline velikost areálu & $21000 \mathrm{~m}^{2}$ & velikost střech & $3000 \mathrm{~m}^{2}$ \\
\hline zadání - odpojení srážkových vod od jednotné kanalizace & & \multicolumn{2}{|c|}{$\begin{array}{l}\text { zadání - porovnání nákladů na rekonstrukci střech s cenou } \\
\text { za přestavbu na střechy vegetační }\end{array}$} \\
\hline odhad investičních nákladů & 5500000 Kč & 6300000 Kč & 3000000 Kč \\
\hline projektová príprava, žádost, výběr zhotovitele & $825000 \mathrm{Kč}$ & 945000 Kč & 450000 Kč \\
\hline celkem & 6325000 Kč & 7245000 Kč & 3450000 Kč \\
\hline dotace z OPŽP (85 \%) & 5376250 Kč & $6158250 \mathrm{Kč}$ & \\
\hline částka z rozpočtu města (15\%) & 948750 Kč & 1086750 Kč & \\
\hline návratnost investice & 6,8 roků & & \\
\hline částka z rozpočtu města (vč. vegetačních střech) & $2035500 \mathrm{Kč}$ & & \\
\hline návratnost investice (vč. vegetačních střech) & 14,5 roků & & \\
\hline
\end{tabular}

Tabulka 3. Odhad investičních nákladů a výpočet návratnosti (zdroj: JV PROJEKT VH, s. r. o.)

Table 3. Estimation of investment costs and payback period (source: JV PROJEKT VH, s. r. o.)

\section{AREÁL NEMOCNICE - PŘÍKLAD 3}

\begin{tabular}{|c|c|c|c|}
\hline poplatek za odvádění srážkové vody za rok 2016 & 232142 Kč & $\begin{array}{l}\text { přestavba střechy se zateplením na } \\
\text { vegetační }\end{array}$ & $\begin{array}{l}\text { rekonstrukce střechy } \\
\text { se zateplením }\end{array}$ \\
\hline velikost areálu & $67000 \mathrm{~m}^{2}$ & velikost střech & $500 \mathrm{~m}^{2}$ \\
\hline \multicolumn{2}{|l|}{ zadání - odpojení srážkových vod od jednotné kanalizace } & \multicolumn{2}{|c|}{$\begin{array}{l}\text { zadání - porovnání nákladů na rekonstrukci střech s cenou } \\
\text { za přestavbu na střechy vegetační }\end{array}$} \\
\hline odhad investičních nákladů & 8100000 Kč & $1050000 \mathrm{Kč}$ & 500000 Kč \\
\hline projektová příprava, žádost, výběr zhotovitele & $1215000 \mathrm{Kč}$ & $157500 \mathrm{Kč}$ & $75000 \mathrm{Kč}$ \\
\hline celkem & 9315000 Kč & 1207500 Kč & 575000 Kč \\
\hline dotace z OPŽP (85\%) & 7917750 Kč & 1026375 Kč & \\
\hline částka z rozpočtu města (15\%) & 1397250 Kč & 181125 Kč & \\
\hline návratnost investice & 6,0 roků & & \\
\hline částka z rozpočtu města (vč. vegetačních střech) & 1578375 Kč & & \\
\hline návratnost investice (vč. vegetačních střech) & 6,8 roků & & \\
\hline
\end{tabular}


Povědomost $v$ oblasti environmentálních věd $v$ souvislosti s HDV, MZI a adaptací na změnu klimatu je u představitelů měst a obcí nevyrovnaná a nedostatečná. Z toho vyplývá nezájem a neochota se vůbec problematikou zabývat, natož nechávat zpracovávat "drahé a složité" dokumentace a metodiky, které přinesou celou řadu nových a neznámých postupů a povinností.

Neznalost ekonomických souvislostí způsobuje to, že vedení měst a obcí vůbec neví, kolik platí za odvádění srážkové vody ze svých nemovitostí a to, že by se těchto poplatků mohli poměrně jednoduše zbavit (tabulka 1-3).

Závěr, který nám z našeho poznání vyplývá, je ten, že adaptace na změnu klimatu je úkol celospolečenského významu, že to bez seriózní role zodpovědného státu, nejvyšší autority, která jde př́kladem svým občanům v systémovosti a koncepčnosti, nevyřešíme.

A k tomu, aby byl proces úspěšný a netrval nepřiměřeně dlouho, je nutné, aby $v$ něj měla veřejnost důvěru. $K$ tomu je nutné, aby měla důvěru ve vládu a své politické reprezentanty, protože tento proces je nutné organizovat ze shora. Proto je uvědomění si důsledků české zkušenosti s ignorováním environmentálních principů stejně důležité, jako je tomu u jiných vážných historických zkušeností v minulosti. Adaptace na změnu klimatu není téma krátkodobé a nemusí být časem jen otázkou našeho blahobytu, ale zdravého života ve městech vůbec. Příkladem nám mohou být ty hospodářsky vyspělé státy, které tématu klimatu věnují náležitou pozornost a investují nebo iniciují investování do prípravy opatření k eliminaci dopadů změny klimatu obrovské finanční prostředky.

Původní príspěvek byl publikován ve sborníku konference Vodní nádrže 2017, ISBN 978-80-905368-5-2.

\section{Literatura}

[1] Projekt RainDROP. (2005-2007). Development of Stormwater Operational Practices Guideline, INTEREG IIIB CADSES Neighbourhood Programme, č. 5C052.

[2] DHI, a. s., a JV PROJEKT VH, s. r. o. Studie odtokových poměrů na území Statutárního města Hradec Králové a prílehlých spádových oblastí. 2011

[3] DHI, a. s., HYDROPROJEKT CZ, a. S., JV PROJEKT VH, s. r. o., a VODIS Olomouc s. r. o. Koncepce vodního hospodářství města Olomouce, Studie odtokových poměrư. 2014.

[4] STRÁNSKÝ, D., KABELKOVÁ, I., BAREŠ, V., VIITEK, J., SUCHÁNEK, M., PLOTĚNÝ, K. a PÍREK, O. Srážková voda a urbanizace krajiny (Pracovní materiál - Metodická pomůcka - vydaná jako součást celoživotního vzdělávání ČKAIT a programu Rady pro podporu rozvoje profese ČKAIT pro obor stavby vodního hospodářství a krajinného inženýrství) - 2011, aktualizace 2018.

[5] VÍTEK, J STRÁNSKÝ D KABEL KOVÁ, L BAREŠ, V a VÍTEK, R. Hospodaření s deštovou vodou v ČR kap. 2.2 Legislativa HDV a její výklad - publikace vydaná v rámci projektu Počítáme s vodou, 2014.

\section{Autor}

Ing. Jiří Vítek

凶vitek@jvprojektvh.cz

JV PROJEKT VH, s. r. o.

Příspěvek prošel lektorským řízením.
HOW TO LEARN THE LEVEL OF LEGAL AND TECHNICAL PRINCIPLES FOR THE APPLICATION OF BLUE INFRASTRUCTURE

\section{VITEK, J.}

JV PROJEKT VH, s. r. o.

Keywords: sustainable drainage systems - blue green infrastructure urban drainage - Operational Programme Environment

The Czech Republic does not sufficiently create the necessary conditions for the conceptual approach to urban drainage based on the principles of a sustainable development. The Ministry of Agriculture of the Czech Republic, responsible for the water management, ignores how much a strict implementation of a sustainable drainage system, especially the blue-green infrastructure, could positively impact urbanized areas' adaptation to climate change. The legal and technical regulations of the Czech civil engineering are in relation to urban drainage nonconceptual and uncoordinated. All responsibility then lies with municipalities that can establish their own guidelines for the application of the blue-green infrastructure. 